\title{
POST METHOD LANGUAGE TEACHING WITHIN THE IMPLEMENTATION OF 2013 CURRICULUM
}

\author{
Hervina \\ STKIP Yayasan Abdi Pendidikan \\ vinaharmyn@gmail.com \\ Submit, 04-07-2020 Accepted, 22-08-2020 Publish, 24-08-2020
}

\begin{abstract}
This research aims to find out know the problem in implementing the 2013 curriculum and offers an alternative solution to this problem by incorporating several principles of post method language teaching. The data were collected through the interview with the English teachers in SMPN 1 Malalak regarding the obstacles they faced in the 2013 curriculum implementation. The data were qualitatively analyzed and the principles of post method language teaching were descriptively incorporated into the problems found in order to provide their alternative solutions. The research findings reveal that the problems of implementing the 2013 curriculum in this school are teachers' unreadiness, students' low level, and application of scientific approach and that the post method language teaching can serve as an alternative solution since it allows more flexibility in the learning process through involving students' and teachers' in the process. In conclusion, the issues in the implementation of 2013 curriculum come from the teachers' and students' as well as the teaching method required to be applied by curriculum. To overcome this, the teachers can apply the principle of post method language teaching in the learning process.
\end{abstract}

Keywords: 2013 Curriculum, Implementation, Post Method Language Teaching

\section{INTRODUCTION}

That the curriculum plays significant roles in language learning is widely agreed by both theorists and practitioners. Curriculum lists all aspects related to how the process of language learning should be carried out in educational institutions. It contains the competency the students to achieve and the teachers need to develop into their teaching material to be taught in the classroom. In addition, curriculum also gives description to the teacher on how the learning material should be presented in the class room. For example, in some curriculum, teachers are only expected to be the facilitator; they are not allowed to present the material by spoon feeding the students. Finally, curriculum also presents the teachers with guidelines of conducting assessment to measure the success of the language learning process. In conclusion, curriculum guides language teachers in preparing, implementing, and evaluating language learning process. 
Given the importance of curriculum in language learning, it is important to develop and improve it for the advancement of the learning process. To that aim, Indonesian government through its ministry of education has developed and revised the curriculum for several time, with the latest revision of 2013 curriculum. In general, the general content of this new curriculum is not that different from the previous curriculum (Ningsih, 2014). However, this curriculum put more emphasis students' participation in the learning process. They are expected to be more active since the teachers are only as facilitators. Besides, this curriculum also expects teachers and students to employ scientific approach in the process of studying the material.

Despite its purpose to help students to achieve the learning objective easily through their active participation, the implementation of 2013 curriculum is not without its controversy as some problems emerge within the learning process using this new curriculum. Some issue emerge in all processes of the learning from the process of instructional preparation to evaluation. Regarding to this process, the teachers do not prepare the good lesson plan and do not understand the principles of scientific approach and the basic concept of 2013 curriculum, so the learning process did not run as it the 2013 curriculum expects (Ekawati, 2017; Nurlisa et al., 2019). Moreover, the teacher also seems to find the problem in the process of assessing students' perfomance due to the fact that the assessment criteria and evaluation process in 2013 curriculum is much more complex especially with the requirement of attitude assessment and the implementation of authentic assessment (Ekawati, 2017; Fitriani, 2017; Khasanah \& Widyantoro, 2017)

In addition to covering the issue in the implementation of 2013 curriculum. Some studies have also been done to investigate the teachers' perspective regarding the response and the solution to this new curriculum. Most of the teachers, especially English teachers, show good attitude and perspective to the new curriculum, but they all believe some revisions need to be done for the betterment of the curriculum so that it can be implemented effectively in the learning process (Nur \& Madkur, 2014; Nurlisa et al., 2019; Zulhernanda, 2018). As for the solution to overcome the problem of 2013 curriculum implementation, the teachers believe that there should be good communication, cooperation, and effort among the government, the educational institututions, and the teachers regarding the implementation and evaluation of this curriculum (Arif \& Sulistianah, 2019) and that there should be a organized continous assistance and training for the teacher on this principle and practice of this curriculum (Gunawan, 2017) as well as the sufficient provision of learning facilities to support the learning process (Zulhernanda, 2018). 
The extensive studies investigating the implementation of 2013 curriculum and its surrounding issues seem to seek solution in terms of building good coordination between the curriculum policy maker and the curriculum practitioner. Therefore, the proposed solutions evolve around the curriculum revision, better coordination among related parties involved in the curriculum making and implementation, conducting training and workshop and the likes as reflected in the aforementioned discussion. In other words, there have been little attention given to seek the solution in terms of language teaching method and its relevance to this issue.

Regarding the teaching method, the 2013 curriculum requires the teacher to implement the use of scientific approach which the language teachers find it difficult to follow due to its rigid step (Apsari, 2017; Ekawati, 2017; Gunawan, 2017; Nurlisa et al., 2019). The use of rigid and single teaching method has been criticized in the language teaching practice. The application of singular language teaching method is not suggested as singular teaching method has limited views of language, teaching, and learning in which the role of the individual teacher is minimized, so it fail to address the broader contexts of language teaching (Swan, 2009). Responding to this issues, post method language teaching is proposed to allow teacher to escape the methodical constrain of particular teaching method (Kumaradivelu, 2006; Kumaravadivelu, 2001). Post method language teaching practice can be utilized as the alternative for the failure of the difficulty of implementing a certain teaching method (Can, 2006), which in this case scientific approach, and this method is effective in the language teaching due its flexible nature and the consideration of teachers' and learners' surrounding aspect in learning process (Khodabakhshzadeh, 2018). Hence, this present paper will attempt to investigate the issues on the implementation of 2013 curriculum and offers insights as to how to solve this issues from the perspective of language teaching method, specifically post language teaching method approach .

\section{LITERATURE REVIEW}

\section{Development and Implementation of 2013 Curriculum}

Of all aspects of education, curriculum is the one with the most significant contribution due to its role in the process of preparing, implementing, and evaluating the process. Curriculum is a set of planning and regulation containing instructional goals, content, and material as well as method that can be used as a guideline in conducting teaching and learning process. to achieve educational objectives (Undang-undang Sistem Pendidikan Nasional Nomor 20 Tahun 2003). In order to keep up with technological advancement, curriculum ideally needs to be changed in order that the learning material presented is not left behind. In 
Indonesian context, there have been eleven revisions of curriculum implemented in educational institutions across this country (Damai et al., 2015).

The new curriculum of 2013 is developed in order to improve the previously used curriculum. Therefore, this curriculum is not different from the previous one in terms of its content in general (Ningsih, 2014). Like its predecessor, this current curriculum is also competency-based. According to Ministry of educational and cultural affairs (2012), this curriculum is competency based which is designed in document, process, or assessment developed from the achievement of instructional goal and content based on Graduates Competency Standard. However, the content of this curriculum is developed into core competency and basic competency different from the previous standard competency and basic competency.

The obvious disparity of this curriculum is seen from the way it is implemented. Unlike the KTSP curriculum which is mostly teacher centered, the 2013 curriculum requires students to be more active in the learning process. For example, the students are sometimes instructed to find the learning materials by themselves through their available resources. It poses challenges as some students are less creative and tend to be passive, so they can fulfill such task. In addition, this curriculum also expects the teachers to employ scientific approach in its implementation. According to Daryanto in (Sofyan, 2016), the steps of implementing scientific approach includes digging through observation, questioning, trial, and then processing the data or information, presenting dataor information, followed by analyzing, reasoning, then concluding and creating. In simple steps, it can be formulated into five stages: Scientific Approach, namely: observing, questioning, collectinginformation or experimenting, associating or information processing, and communicating (Sarwati, 2016)

\section{Language Teaching Method}

Along its history, many experts of second or foreign language teaching and learning have established and introduced many methods that can be used in the process of teaching and learning. Such methods significantly contribute to the learning outcome because they offer some ways to assist the learners comprehend the second language they learn. Richard \& Rogers (2004) defines second language teaching method as follow,Language teaching methodology can be defined as the notion of a systematic set of teaching practices based on a particular theory of language and language learning.

From the definition above, it is clear that the second language teaching method should be both systematic and based on theory of language and learning techniques. To begin with, systematic language teaching method is that the techniques and the steps within the method should be applied in the sequence 
order by the teacher in order that the learning process will be running well and the goal will be achieved successfully. In addition to systematic, language teaching method, according to the definition, should be based on theory language and theory of learning. It means that every language teaching method is established and developed based on the certain language and learning theory. For example, Audio-Lingual Method is developed based on the structuralist language theory and the behaviourist learning theory.

As suggested above, language teaching method is developed from the different language and learning theory and also the different dimension; accordingly, one method will be different from another method. Since each method is different, they will have the different language teaching practice that should be followed by the teacher. These differences will also result in the limited of language scopes available to be taught in a certain method. Therefore, language teaching with only one method based will unlikely run well. On the other hand, there is implied notion language teaching method for the teachers to apply this certain method solely. This phenomenon raises the issue of questioning of the necessity of language teaching method in this current context and leads to the birth of post method language teaching theories.

\section{Post Method Language Teaching}

The notion of post method era in language teaching appears as the response to the problematic issues related to a wide range of language teaching methods proposed. According to Swan (2009), there have been successive and often contradictory views about how best to teach languages. Each method claims it can teach language most effectively if it is applied in language learning classroom. Brown (2002) mentions, "a method is a set of theoretically unified classroomtechniques thought to be generalizable across a wide variety of contexts and audiences." This view suggests that language teaching method gives prescribed dictation to language teachers in running language classroom regardless the context and subject of learning. Responding to this phenomenon, a post-method pedagogy is envisioned as resistance for the inclusion of voices, for the incorporation of dialogue, and for the recognition of the forces which permeate formal education (Banegas, 2014).

The tendency of language teaching method to single out other factors is also reviled by Swan (2009). He asserts that the language teaching methods' efficiency cannot be demonstrated as they are not testable against each other, and it fails to address the broader contexts oflanguage teaching. Moreover, Kumaravadivelu (2006) mentions, 'By concentrating excessively on method, we have ignoredseveral other factors that govern classroom processes and practices factors such as teacher cognition, learner perception, societal needs, cultural 
contexts, political exigencies, economic imperatives ....' This view implies there are other factors of learning ignored by language teaching method but it needs to be resolved in order to make the learning process run well. In line with this, Swan (2009) claim that the failure in language teaching is not method related but that of these previous factors which tend to be ignored in learning process.

Related to the practical implementation of post method language teaching, Kumaravadivelu (2006) proposed 10 macrostrategies framework. However, only four will be discussed in here due to the suitability with the issue in curriculum 2013 implementation:

1. Maximize learning opportunities. The first macrostrategy envisages teaching as a process of creating and utilizing learning opportunities. Teachers are seen both as creators of learning opportunities for theirlearners and utilizers of learning opportunities created by learners. As creators of learning opportunitiesteachers need to strike a balance betweentheir role as planners of teaching acts and their role as mediators of learning acts.

2. Facilitate negotiated interaction. This macrostrategy refersto meaningful learner-learner, learner-teacher interaction in class wherethe learners have the freedom and flexibility to initiate and navigate talk,not just react and respond to it.

3. Activate intuitive heuristics. One way of activating the intuitive heuristics of the learner is to provide enough textual data so that the learner can infer certain underlying rules of form and function. A good deal of linguistic and discoursal information can be conveyed, not directly through rules, but indirectly through examples. Learners may be encouraged to find the rule-governing pattern in the examples provided.

4. Promote learner autonomy. Because language learning is largely an autonomous activity, promoting learner autonomy isvitally important. It involves helping learners learn how to learn, equippingthem with the metacognitive, cognitive, social,and affective strategies necessary to selfdirect their own learning, raisingthe consciousness of goodlanguage learners about the learning strategies.

\section{RESEARCH METHOD}

It is a descriptive study, which attempts to describe the phenomena of the 2013 curriculum implementation in the field related to its challenges and issues. The writer focuses on exploring the learning process related issues and offers some insights on how these issues might be solved by using several principles and frameworks underlying post method language teaching theory. To obtain the field data, the writer did the interview with an English teacher who implements the 2013 curriculum in her class. The interview was done to English teacher in SMPN 
1 Malalak. The data from this interview will be qualitatively described and analyzed against the theory of post method.

\section{FINDINGS}

Based on the interview with the English teacher in this school, the writer was informed about the problems in implementing the 2013 curriculum. The first problem is related to readiness. The teacher claimed that the implementation of this curriculum seems to be sudden without well preparation. Although they did have workshop and training, it was not really helpful due to the limited frequency of this workshop. Besides, some training instructor and trained teachers did not clearly explained about the workshop materials. In addition, she also said that the requirement for teacher to prepare attractive learning media or technology-related media is also a challenge. The problem is not only in limited available resources but also in teachers' lack ability in using advanced technology. Moreover, some of them also have heavy workload. In short, the implementation of the 2013 curriculum seems to pay less attention to teachers' aspect. The government simply expects the teachers to implement it.

The second issue is related to students. The teacher informed that her students were not ready to be taught with the 2013 curriculum due to their low level. When expected to active in the learning process, the students did not respond actively. Despite the student centered learning, the process is still dominated by the teacher. Teacher mostly handles the classroom and directs the process of learning due students' passivity in learning process. Apart from being passive, students are also difficult to comprehend the material because some are too advanced for them.

The last issue is related to teaching method. The writer was informed the use of scientific method in presenting material poses the biggest challenge to the teachers. The teachers found that the requirement to apply the sequential steps of scientific approach due to the limited allocated time. She mentioned that some of the steps are not applicable in language learning, but it is more applicable in teaching science related subject. In addition, she stated that it would also make the learning monotonous since the material were presented in the arranged step. When asked what method she used in teaching, she answered that she just followed the textbook and worksheet. In addition, if it was practiced, the application of scientific method was only in the first step i.e observing due to the students ' low level. Sceintific approach requires students' high order level of thinking because in the end they are expected to analyzing, evaluating, and creating. These expectation seems to be unrealistic for students especially junior high school with that kind of competency. She concluded that in terms of how the material is presented teachers mostly use KTSP. 


\section{DISCUSSION}

The interview reveals that the issues the teacher face within the implementation of 2013 curriculum fall into three aspects i.e. readiness, students, and teaching method. In terms of readiness, the teachers feel that the curriculum policy makers do not seem to give them sufficient preparation before implementing the new curriculum. Thus, revision in terms of better coordination among the government as the policy makers and the teachers as the practitioner is highly needed as also suggested by the previous studies (Nur \& Madkur, 2014; Nurlisa et al., 2019; Zulhernanda, 2018). Moreover, the teachers also find that it is quite challenging for them to practice the use of techology-based media and education in the implementation of the curriculum. The use of technology is not only apparent in the practice of language teaching as the society is moving to the paradigm of industry 4.0 but also necessary in 2013 curriculum (Sarwati, 2016). However, it is quite difficult for the teachers to adapt to this (Ekawati, 2017). Finally, the teachers also find the challenges in the process of assessment and evaluation due to the intricate nature of 2013 curriculum evaluation. This issue is also evident in several studies (Ekawati, 2017; Fitriani, 2017; Khasanah \& Widyantoro, 2017).

The second issue is related to students' ability. The challenges mostly stem from the fact that most students' in this school still have low ability, so the materials and instructional process of 2013 curriculum, which is students-centered and uses scientific approach (Damai et al., 2015; Sarwati, 2016), do not seem to fit their learning style and preferences. In other words, the teachers are still dominant in the learning process although the curriculum suggests otherwise.

Finally, the teaching method outlined in 2013 curriculum also poses challenges to the teachers when teaching English in this school. As suggested previously, the 2013 curriculum requires the application of scientific approach in the instructional process. The teachers claim that it is difficult for them to follow the sequences of scientific approach as some of the steps are not applicable for some learning materials. The similar challenges are also voiced by the teachers in the previous conducted studies on the implementation of 2013 curriculum for English subject (Apsari, 2017; Ekawati, 2017; Gunawan, 2017; Nurlisa et al., 2019).

The application of singular language teaching method is not suggested as singular teaching method has limited views of language, teaching, and learning in which the role of the individual teacher is minimized, so it fail to address the broader contexts of language teaching (Swan, 2009). Responding to this issues, post method language teaching is proposed to allow teacher to escape the methodical constrain of particular teaching method (Kumaradivelu, 2006; Kumaravadivelu, 2001). Post method language teaching practice can be utilized as the alternative for the failure of the difficulty of implementing a certain teaching 
method (Can, 2006), which in this case scientific approach, and this method is effective in the language teaching due its flexible nature and the consideration of teachers' and learners' surrounding aspect in learning process. Hence, it is possible that some selected principles of this post method language teaching can be used to solve the issue of 2013 curriculum implementation, especially in English subject.

Regarding this issue, four mactrostrategies of post method, proposed by Kumaradivelu (2006) might also lend help to overcome the issues of implementing the 2013 curriculum in Indonesia in general and especially in SMPN 1 Malalak as follows:

1. Maximize learning opportunities. In this principle, the teachers are expected to provide learning opportunities to students as they are seen as creators of learning opportunities. As the curriculum is students centered learning process, students need to be involved in wider learning opportunities. The teachers complain that students tend give lack enthusiastic response when given task from which the learning opportunity is available. In language learning, teachers can vary the assignments by relating them to students' interests. Rather than textbook based learning opportunity, the teachers can assign students to watch movies or analyze songs related to the material because language learning sources are widely available not only in design textbook.

2. Facilitate negotiated interaction. This macrostrategy refersto meaningful learner-learner, learner-teacher interaction in class wherethe learners have the freedom and flexibility to initiate and navigate talk,not just react and respond to it. Facilitating interaction can overcome students' passivity in learning. Teachers tend to understand that students' active participation is show through their willingness to respond to their explanation and questions. Therefore, the teacher in both active and passive classroom directs the classroom interaction. Meanwhile, students can also learn from their friend and will likely participate in such learning due to their equality in learning. Therefore, teachers are required to provide possibility for learner-learner interaction and in some occasion allows learners to direct classroom interaction. It can be done pair work, group work, peer tutorial, leaning games etc. the group must be designed in such a way that the good students can help the low achieved ones.

3. Activate intuitive heuristics. One way of activating the intuitive heuristics of the learner is to provide enough textual data so that the learner can infer certain underlying rules of form and function. It correlates with the first step of scientific approach of observing in which students are expected to observe phenomena related to the material and draw their conclusion about them. It is commonly practiced by showing students pictures or text model with its lexicogrammatical features. To activate students' intuitive heuristic, teachers can 
present them with interesting material so it will attract them. Rather than using pictures, teacher can use video or clip taken from the movie which is related to the material. Rather than by using boring text to study grammatical features, teachers can use song lyric. Once they become interested, students will likely be able to understand such material in this step.

4. Promote learner autonomy. Learning autonomy is necessary because at the end of the process, students are expected to create. Related to language learning, students are expected to produce text and utterances. To achieve this, teachers need to gradually decrease their intervention in learning process, so students will not be fully dependent. It is also necessary for teachers to equip learners with the strategies they can used so they can solve some problems in language with the metacognitive, cognitive, social, and affective strategies necessary to selfdirect their own learning.

\section{CONCLUSION}

From the above findings and analysis, it can be concluded that the issues of implementing the 2013 curriculum in SMPN 1 Malalak are teachers' readiness, students' low level, and teaching method. To solve this issue, post method language teaching principles can be incorporated because it enable teachers to give more interesting learning opportunities to enable the process of student centered learning, to reduce students' passivity through more learner-learner interaction and learner directed interaction, to activate students' intuitive heuristic, and to help students gain learning autonomy to reach the goal of language production.

\section{REFERENCES}

Apsari, Y. (2017). Teachers' Problems and Solutions in Implementing Curriculum 2013. Acuity: Journal of English Language Pedagogy, Literature and Culture, 3(1), 11-23. https://doi.org/10.35974/acuity.v3i1.620

Arif, M., \& Sulistianah, S. (2019). Problems in 2013 Curriculum Implementation for Classroom Teachers in Madrasah Ibtidaiyah. Al Ibtida: Jurnal $\begin{array}{llll}\text { Pendidikan Guru } & \text { MI, } & 6(1), & 110 .\end{array}$ https://doi.org/10.24235/al.ibtida.snj.v6i1.3916

Banegas, D., L. (2014). of methods and post methods (Selected Papes from the 39th FAAPI Conference).

Brown, H., D. (2002). Principles of Language Learning and Teaching (Fifth). Pearson Education.

Can, N. (2006). Post-Method Pedagogy: Teacher Growth behind Walls. Proceeding of the 10th METU ELT Convention.

Damai, A., Krissandi, S., \& Rusmawan, R. (2015). The Constraints of Elementary School Teachers. Cakrawala Pendidikan, 36(3), 457-467.

Undang-Undang Nomor 20 Tahun 2003 Tentang Sistem Pendidikan Nasional. 
Ekawati, Y., N. (2017). English Teachers' Problems in Applying the 2013 Curriculum. English Review: Journal of English Education, 6(1), 41-48. https://doi.org/10.25134/erjee.v6i1.769

Fitriani, F. (2017). Authentic Assessment, Implementation, Curricullum 2013. Getsempena English Education Journal (GEEJ), 4(2), 164-171.

Gunawan, I. (2017). Indonesian Curriculum 2013: Instructional Management , Obstacles Faced by Teachers in Implementation and the Way Forward. Advances in Social, Education and Humanities Research, 128(Icet), 5663.

Khasanah, R., U., \& Widyantoro, A. (2017). The Problems in the Implementation of the 2013. Conference on Language and Language Teaching

Khodabakhshzadeh, H. (2018). The Relationship between English Foreign Language Teachers, Willingness with Post-Method Pedagogy and Their Teaching Effectiveness. International Journal of Instruction, 11(2), 425436.

Kumaradivelu, B. (2006). Understanding Language Teaching: from Method to Post Method. Lawrence Erlbaum Associates.

Kumaravadivelu, B. (2001). Toward a Postmethod Pedagogy. TESOL Quarterly, 35(4), 537-560.

Ningsih, U. (2014). Analisis Kesulitan Guru Matematika Kelas VII dalam Menerapkan Kurikulum 2013 di SMPN 12 Surakarta. Universitas Muhammadiyah Surakarta.

Nur, M., R., \& Madkur, A. (2014). Teachers' Voices on the 2013 Curriculum for English Instructional Activities. IJEE (Indonesian Journal of English Education), 1(2), 119-134. https://doi.org/10.15408/ijee.v1i2.1340

Nurlisa, N., Sada, C., \& Ikhsanudin, I. (2019). The English Teachers 'Perceptions and Problems in Implementing Curriculum 2013 in Senior High School. International Conference on Teaching and Education

Richards, J., C., \& Rodgers, T., S. (2004). Approaches and Methods in Language Teaching. Cambridge University Press.

Sarwati, S. (2016). Scientific Method in English Language Teaching. Transformatika, 12(1), 60-75.

Sofyan, A. L. I. (2016). The Implementation of Scientific Approach in English Language Teaching Based on Curriculum 2013 in SMK Negeri 2 Sragen in the Academic Year of 2015 / 2016. Universitas Muhammadiyah Surakarta.

Swan, M. (2009). Contemporary Applied Linguistics (V. Cook \& L. Wei (eds.); 117-136). Continuum.

Zulhernanda, W. (2018). Teachers ' Perceptions on Application Of 2013 Curriculum for Elementary School in Medan. Advances in Language and Literary Studies, 9(1), 62-66. 